\title{
EXPLORING STUDENTS' DIFFICULTIES IN COMPREHENDING READING FOR ACADEMIC MATERIALS USED IN THEIR CLASS
}

\author{
${ }^{1)}$ Ratih Inayah, ${ }^{2}$ Silpia Rahayu \\ ${ }^{1,2)}$ Program Studi Pendidikan Bahasa Inggris, STKIP Siliwangi
}

\begin{abstract}
There is a positive correlation between students academic reading skills and their writing skill (Inayah, 2010). This researchexplored students difficulties in comprehending reading for academic materials used in their classroom. This research usedcase study as an intensive, holistic description, and analysis of a single instance, phenomenon, or social unit (Silverman, 2005). The study employed a descriptive method with multi instruments as observation, questionnaires, and interviews. Populations of this research were taken from a class of reading for academic purposesstudents at STKIP Siliwangi Bandung and the sample were taken from two high achievers and two low achievers from the classroom. The result showed that students' behavior lead them to reading difficulty, those who are not interested reading activity, relatively get trouble in reading for academic purposes. This study showed that students who experience difficulty with reading often develop problems with motivation and self confidence. Individuals with reading problems are more likely to attribute failure to a lack of personal ability or intelligence so that they cannot recognize their true skill.
\end{abstract}

Keywords: Reading Skills, Reading for Academic Purposes

\begin{abstract}
ABSTRAK
Ada korelasi positif antara kemampuan membaca siswa akademik dan keterampilan menulis mereka (Inayah, 2010). Penelitian ini mengeksplorasi kesulitan siswa dalam memahami bacaan untuk bahan akademik yang digunakan di dalam kelas mereka. Ini studi usedcase penelitian sebagai intensif, deskripsi holistik, dan analisis contoh, fenomena, atau unit sosial tunggal (Silverman, 2005). Penelitian ini menggunakan metode deskriptif dengan multi instrumen observasi, kuesioner, dan wawancara. Populasi dari penelitian ini diambil dari kelas membaca untuk tujuan akademik siswa di STKIP Siliwangi Bandung dan sampel diambil dari dua berprestasi tinggi dan dua berprestasi rendah dari kelas. Hasil penelitian menunjukkan bahwa perilaku siswa memimpin mereka untuk membaca kesulitan, mereka yang tidak tertarik kegiatan membaca, relatif mendapatkan kesulitan dalam membaca untuk tujuan akademik. Studi ini menunjukkan bahwa siswa yang mengalami kesulitan dengan membaca sering mengembangkan masalah dengan motivasi dan kepercayaan diri. Individu dengan masalah membaca lebih cenderung untuk atribut kegagalan untuk kurangnya kemampuan pribadi atau intelijen sehingga mereka tidak dapat mengenali keterampilan mereka yang sebenarnya.
\end{abstract}

Kata Kunci: Keterampilan Membaca, Membaca untuk Keperluan Akademik

\section{A. INTRODUCTION}

To master English is an International language is very essential nowadays. For students who study in English major, English is not only used in communication but also for everyday learning academically in the classroom. According to Alwasilah (2010) the role of English as a foreign language in Indonesia has been so advanced and strategic. Students who learn in English major learn English in their daily life as an introductory language and they study a material through English. According to Bowden and Marton (2000) to be successful in university level, it depends on the mastery of some fundamental academic skills.

Reading is one of the prominent skills to reach successful result in university. Reading an academic text actually is not a simple process. If aesthetic reading is for entertainment, however efferent reading is reading to gain information; the focus is on the information in the text and illustration and not focused on the experience of reading for entertainment. Students are expected to read a text with the sense of the writer; it means that as a reader she or he can easily understand the 
intention of the writer. The realities nowadays still show that some students find difficulties in reading for academic materials. In this case, identified as the core skill in academic setting, the importance of reading skill is very meaningful. As one of the aims to teach reading is to enable the students to comprehend the text in a good way. We consider that reading has a key role in almost every course of study. Yet many students do their reading in an unfocused way. This can often lead to poor results.

One of the main reasons that we read is to study. While we are still study in school, many things we know comes from the texts that we read. There are some findings regarding to students' difficulties in reading, Smith (1990) explored the relationship of adults' reading attitude to actual reading behavior. The results showed that attitude toward reading bears an important relationship to daily reading behavior. Adults with positive attitudes toward reading were found to perform better on standardized reading tests, read more often, and read a wider variety of reading materials than did adults with negative attitudes.

Referring to those explanations above, the study was aimed to seek the students' difficulties in comprehending reading for academic materials used in their class and to know their strategies to solve the problems.

Therefore, the research questions are :

1. What are students' difficulties when reading Academic English texts?

2. What are students' strategies and skills to solve the problems?

3. What is students' attitude toward reading for Academic Purposes Course?

This research was conducted in STKIP Siliwangi Bandung. The population of this study were students of English Education Study Program class A2 register year of 2013 who take English for Academic Purposes Subject. The samples will be taken from two high achievers and two low achievers from the classroom

\section{B. LITERATURE REVIEW AND METHODOLOGY}

\section{Literature Review}

\section{a. The Nature of Reading}

Reading is a key of knowledge. One of the essential reasons that we read is to study more.
While we are still in college or university, many things we know come from the texts we read. According to Chen (2005) reading is a very complex process that needs so much active participation from the reader.

According to Erickson, Peters, and Strommer (2006) studying a discipline, in this case students who learn in English major will give them a chance to be involved with the ways of being, writing, seeing, and thinking of the world of those expert and give them opportunity to be part of the culture of the discipline and facilitates learning, and skill. In line with Howards (2005) states that as a reader student must negotiate the meaning with the author means that a reader should read in the sense of the writer.

Reading an academic text actually is not a simple process. Students must be able to read a text with the sense of the writer; it means that reader can understand the intention of the writer. Shanahan (1988) states that teachers should provide and give students with meaningful literacy experiences so that they can read and in some situations for some reasons. Reading can be a part of student's habit in every day life, wherever they are, for example by giving students chance to do deep approach reading, it is expected to be able to enrich and develop student's literacy experience.

According to Tierney and Caplan (1989) Students' relationship with an author can develop when they are reading the materials. "Everything points to the necessity of learning to write from what we read" (Smith, 1983)

According to Mayo (2000) as a teacher we can motivate students to experience reading in interesting way so that they can increase the quality as a reader. Teachers should give the opportunity to respond to literature as a reader as well as examine the writer's style to see what raised the reader's response. Students should be able to analyze the text and understand the intention and meaning of the text.

According to Smith (1983) reading like a writer allows student to actually become a writer. When reading like a writer, in order to make meaning of the text, the reader takes in and learns from the author's style, use of conventions and the like. When reading like a writer, the reader uses the author's text as a model for texts that he or she reader will finally write. 
As a reader we also sometimes place ourselves in the place of the author in order to get a personal perspective that develops our own responses or interpretation (Purves, 1993) It is important to make sure that your reader can easily understand the information you give him. Every idea should be clearly developed and clearly expressed and the relationship between ideas should be explicit.

In reading, readers' knowledge is transferred by the writers. In this case the reader will gain the knowledge that the writers know and will receive it in various ways. Rubin \& Hansen (1986) suggests that different types of knowledge that can be recognized through reading instruction might transfer to writing instruction: informational knowledge, structural knowledge, aesthetic knowledge, and process knowledge.

\section{b. Academic Discipline and Academic Reading}

The students' academic discipline also decide their reading habits, as well as influences how much students spend time on academic reading. Regardless of academic discipline, students' behavior and self-attitude of proficiency when using digital resources influence how they choose to access their reading materials (Mokhtari, Reichard and Gardner, 2009). As Howards (2005) describes "Reading is commonly referred to as a process, but when you study what happens when people learn to read quickly discover that reading involves many process simultaneously". In academic reading, efficient readers do not always read every word. To save time, they use techniques like skimming, scanning and searching. When we skim through a text, we are reading it quickly to get an overall impression of the text. When we are scanning or searching a text we are looking for specific information which we know, or suspect, is there. Below, figure 1 this diagram is based on Reading process (Urquhart and Weir, 1998).

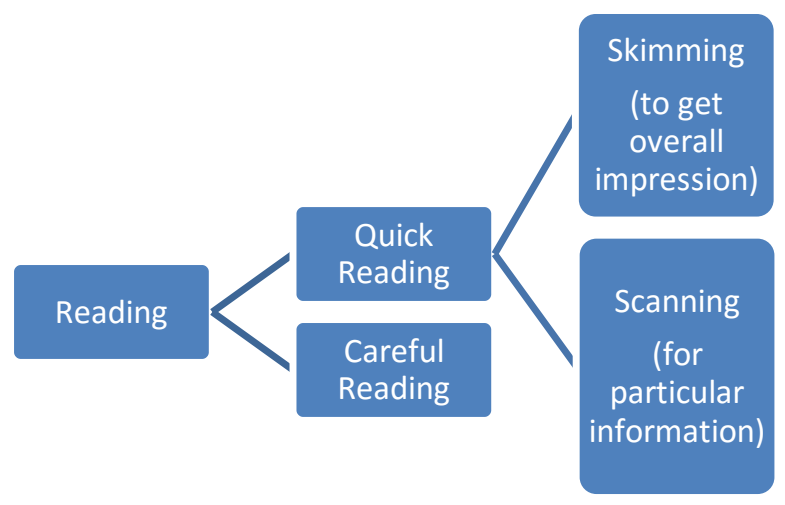

\section{c. Teaching Style and Academic Reading}

A survey conducted on the attitudes of undergraduate foreign language literature students towards reading indicates that while motivation and an enjoyment of reading help to shape reading habits, the learning styles and preferences of an individual, as well as the instructional methods that encourage and set expectations for how students interact with their reading materials, are also important factors for reading behaviour (Davis, CarbónGorell, Kline and Hsieh, 1992, p. 325).

Students should be given the time and chance to express their opinions and personal reactions to a text in some essays, rather than merely instructed to memorize facts and figures, enjoyed and involved more with their reading text. Freedom over text choice and selection of reading materials was also found to correspond to a more interesting attitude towards both aesthetic and efferent reading. This last finding has potential implications for academics examining what role university reading lists can play in undergraduate approaches to academic reading, particularly if such lists provide students with a varied selection of sources from which to choose. Efficient readers do not always read every word. To save time, they use techniques like skimming, scanning and searching. When we skim through a text, we are reading it quickly to get an overall impression of the text. When we are scanning or searching a text we are looking for specific information which we know, or suspect, is there.

\section{d. Previous Research}

In a study, Smith (1990a) examined reading habits and attitudes $t$ different levels of education and occupation. Subjects completed questionnaires about their reading attitudes, reading habits, and perceptions about reading. Smith found that adults with more education and higher-status occupations had positive attitudes toward reading and reported spending more time reading than did those with less education and lower-status occupations. In addition, adults with more education rated their own reading ability higher than did those with less education.

In another study, Smith (1990b) explored the relationship of adults' reading attitude to actual reading behavior. The results showed that attitude toward reading bears an important relationship to daily reading behavior. Adults with positive 
attitudes toward reading were found to perform better on standardized reading tests, read more often, and read a wider variety of reading materials than did adults with negative attitudes. With these findings, the author reinforced the importance of developing positive attitudes toward reading among students to promote the high levels of reading activity needed for a successful college education.

\section{Methodology}

This study employed qualitative research paradigm for a classroom setting. According to Alwasilah (2001), the classroom qualitative research has many advantages. The first is that the researcher can describe adequately the classroom climate; the second is the researcher can understand the nature of the class, and the third is the researcher can respond to present circumstances, beliefs, and attitudes.

The study is based on descriptive method, according to Alwasilah (2011) the descriptive method is claimed to have some benefits. The first is it goes deeply to the topic measured, it is to ensure a depth discussion on the topic. The second is it provides the researcher with data recorded, so it makes that possible for researcher to revise the data obtained in order to have in depth analysis. As a case study, the present study is contextual and will be conducted in specific situation.

Research question number one is answered qualitatively. This research was conducted to find out students' difficulties when reading Academic English texts. Conversely, observational studies have been fundamental to this qualitative research. This study combines observation with interviewing, also questionnaire. This is because the researchers have several research questions and because we want to use different methods or sources to corroborate each other so that we are using some form of methodological triangulation (Mason, 1996).

As a qualitative researcher, we believe that qualitative methods can provide a 'deeper' understanding of social phenomena than would be obtained from purely quantitative data, as Denzin and Lincoln put it this way:

Qualitative researchers stress the socially constructed nature of reality, the intimate relationship between the researcher and what is studied, and the situational constraints that shape inquiry. They seek answers to questions that stress how social experience is created and giving meaning. In contrast, quantitative studies emphasize the measurement and analysis of causal relationships between variable, not process. Proponents of such studies claim that their work is done from within a value-free framework. (2000:8, authors' emphasis)

This research was conducted in STKIP Siliwangi Bandung. The population of this study are students of English Education Study Program class A2 register year of 2013, they have already taken English for Academic Purposes Subject in the previous semester. The samples were taken from two high achievers and two low achievers from the classroom.

The setting of the research used both 'closed' or 'private' setting where access is controlled by gatekeepers, also 'open' or 'public' settings where access is freely available but not always without difficulty either practical or ethical.

The procedures of the research are as follow:

First of all, the researchers prepare the instruments to be used in the research. In the same weeks we also recruit the participants and ask them to be participated in the study. Once this is completed the researchers then can start to collect data. Next, the questionnaires were then given to the students, after that the interviews were given to get more information. Focus interview: you keep on to the issue, you interview the people, you would be asking them that the question you analyze focus interview is to get people understanding. Then the researchers code the answers of the students.

In this qualitative research, ethical issues are much more to the fore. For instance, as a qualitative researchers who study human subjects ponder over the dilemma of wanting to give full information to subjects but not 'contaminating' our research by informing subjects too specifically about the research question to be studied.

Moreover, when we are studying people's behavior or asking them questions, not only the values of the researcher but also researcher's responsibility to those studied have to be faced. One way to keep participants' privacy is to let them know that we have ethical code in doing research. 


\section{FINDINGS AND DISCUSSION}

\section{Students' Difficulty in Comprehending Reading Text Material}

This study has showed a useful insight into the academic reading practices of STKIP Siliwangi students. It is not possible to generalize these findings beyond the College but some significant findings are present. In our finding, students' behavior lead them to reading difficulty, those who do not like reading activity, relatively get trouble in reading for academic purposes.

This study showed that students who experience difficulty with reading often develop problems with motivation and self confidence. Individuals with reading problems are more likely to attribute failure to a lack of personal ability or intelligence and hold inaccurate perceptions of their true skill. The link between reading difficulty and self confidence related specially with students' feeling, especially as readers.

Academic reading was primarily motivated by course, assignment also examination requirements. The majority of students $(60 \%)$ read for between one and seven hours per week read for 21 hours or more. Significant differences did not exist between the genders. The time spent reading per week increased as students progressed through their academic career.

\section{Students' Strategies and Skills to Solve the Problems}

This study has identified some characteristics that differentiate high achievers from the low achievers. Low achievers tend to be focus on decoding single words, fail to adjust their reading for different text or purposes, and seldom look ahead or back in text to monitor and improve comprehension. Low achievers tend to be nonstrategic as well. For example, low achievers focus energy on looking busy and following directions, but remain unaware of comprehension difficulties or strategies for ameliorating comprehension failure.

In fact, when given passage containing inconsistent information, low achievers do not reread the parts in which inconsistencies occur, and they fail to ask questions or request assistance to clarify difficulties. Low achievers believe that the purpose of reading is to pronounce words correctly. When asked to summarize, they often recite sentences from the text verbatim without conveying and understanding of the material.

In contrast, high achievers use efficient decoding strategies that rely more on processing units of thought and less on word by word reading. They adjust reading speed according to text difficulty or purpose and monitor comprehension during reading activities. Furthermore, high achievers summarize information accurately, clarify difficulties encountered in text, and predict what is likely to come next. High achievers understand that making sense out of text, rather than accurate word reading, is the goal of reading, and they select appropriate methods to attain this goal. In sum, high achievers are characterized as active and strategic readers, they understand the purpose of reading, continuously monitor comprehension, and take corrective action when comprehension failure occurs.

\section{Students' Attitude toward Reading for Academic Purposes}

In the questionnaire, there were fifteen statements which covered three components of attitude. The students' responses to items were recapitulated and the data were analyzed and interpreted.

To answer research question, what is students' attitude toward reading for academic purposes? A questionnaire was given to 25 students. If the statement is positive, it means that the scale is Strongly agree $=5$, Agree $=4$, Neutral $=3$, Disagree $=2$, Strongly disagree $=1$. While if the statement is negative, it means that the scale is Strongly agree $=1, \quad$ Agree $=2, \quad$ Neutral $=3$, Disagree $=4$, Strongly disagree $=5$

The lowest score was 375 , and the higher score was 1879. After the answers of the 25 students were calculated, then it found that the result of students' answer is 1200 .

Table 4.6 Students' Attitude toward reading for academic purposes

\begin{tabular}{lll}
\hline No & \multicolumn{1}{c}{ Range } & $\begin{array}{c}\text { Student's Attitude } \\
\text { Level }\end{array}$ \\
\hline $\mathbf{1}$ & $\mathbf{3 7 5 - 6 7 5}$ & Very negative \\
$\mathbf{2}$ & $\mathbf{6 7 6 - 9 7 6}$ & Negative \\
$\mathbf{3}$ & $\mathbf{9 7 7 - 1 2 7 7}$ & Neutral \\
$\mathbf{4}$ & $\mathbf{1 2 7 8 - 1 5 7 8}$ & Positive \\
$\mathbf{5}$ & $\mathbf{1 5 7 9 - 1 8 7 9}$ & Very positive \\
\hline
\end{tabular}


According to the table, 1200 is included to neutral level, because neutral level is in Range 977-1277.

\section{CONCLUSION}

The main purpose of the study was to know students' difficulties when reading Academic English texts, and to know students' strategies and skills to solve the problems? Also to know students' attitude toward reading for Academic Purposes. The result indicated that students' behavior toward reading lead them to have difficulty in reading for academic purposes.

Subjects in low achievers spent less time reading and read a narrower variety of academic reading materials. However subjects in high achievers spent more time reading and read a wider variety of academic reading materials. The data also revealed that, however well or poorly these students read they spend more time on academic reading than any other type of reading in university. In sum, reading can be seen as an activity in which there is a strong attitude-behavior connection.

\section{E. REFERENCES}

Alwasilah, A.Chaedar. 2011. Pokoknya Kualitatif: Dasar-dasarMerancang danMelakukan Penelitian Kualitatif. Bandung. Pustaka Jaya

Bowden, J. \& Marton, F. 2000. The University Of Learning. London: Kogan Page.

Chen, Luzan. 2008. The Reading Habits of Adults. English Journal 15, (1) 17-27

Erickson, B. L., Peters, C. B., \& Strommer, D. W. 2006. Teaching first-year College students. San Francisco, CA: Jossey-Bass.

Howards,G. 2005. Constructing Meaning in Reading. American Journal of Education, 103, 160- 183.

Harmer, Jeremy. 2002. ThePractice of English Language Teaching. New York: Longman, Inc.

Inayah, Ratih. 2010. Correlational Study between Senior High School Students' Reading Comprehension and their Writing Skill. Skripsi S.Pd Universitas Pendidikan Indonesia.

Mayo, L. (2000). Making the Connection: Reading and Writing Together. English Journal, 89 (4), 74-77.
Mokhtari, Kouider \& Sheorey, Ravi (1994) Reading Habits of University ESL students at Different Levels of English Proficiency and Education. Journal of Research in Reading 17 (1), 46-61.

Purves, A. C. (1993). Toward a Revaluation of Reader Response and School Literature, Report Series 1.8. Albany, NY: National Research Center on the Teaching and Learning of Literature, University at Albany.

Shanahan, T. (1988). Reading-Writing Relationships, Thematic units, Inquiry

Learning in pursuit of effective integrated literacy instruction. The Reading Teacher,51 (1), $12-20$

Smith, F. (1990). Reading Like a Writer. Language Arts, 60 (5), 558-567.

Silverman, David. 2005. Doing Qualitative Research: A Practical Handbook. London. Sage Publications Ltd.

Tierney, R. J., Caplan,R., Ehri, L., Healy, M., \& Hurlow, M. (1989). Writing and

Reading Working Together. In A. H. Dyson (Ed.). Collaboration through Writing and Reading: Exploring Possibilities. (pp. 169209) IL: National Council. 